Volume 45 | Issue 1

2012

\title{
Targeted Killing: When Proportionality Gets All Out of Proportion
}

Amos Guiora

Follow this and additional works at: https://scholarlycommons.law.case.edu/jil

Cart of the International Law Commons

\section{Recommended Citation}

Amos Guiora, Targeted Killing: When Proportionality Gets All Out of Proportion, 45 Case W. Res. J. Int'1 L. 235 (2012) Available at: https://scholarlycommons.law.case.edu/jil/vol45/iss1/21

This Article is brought to you for free and open access by the Student Journals at Case Western Reserve University School of Law Scholarly Commons. It has been accepted for inclusion in Case Western Reserve Journal of International Law by an authorized administrator of Case Western Reserve University School of Law Scholarly Commons. 


\title{
TARgeted KiLling: When \\ Proportionality Gets All Out of PROPORTION
}

\author{
Amos N. Guiora*
}

Targeted killing sits at the intersection of law, morality, strategy, and policy. For the very reasons that lawful and effective targeted killing enables the state to engage in its core function of self-defense and defense of its nationals, I am a proponent of targeted killing. However, my support for targeted killing is conditioned upon it being subject to rigorous standards, criteria, and guidelines. At present, new conceptions of threat and new technological capabilities are drastically affecting the implementation of targeted killing and the application of core legal and moral principles. High-level decision makers have begun to seemingly place a disproportionate level of importance on tactical and strategic gain over respect for a narrow definition of criteria-based legal and moral framework. Nonetheless, an effective targeted killing provides the state with significant advantages in the context of counterterrorism. Rather than relying on the executive branch making decisions in a "closed world" devoid of oversight and review, the intelligence information justifying the proposed action must be submitted to a court that would ascertain the information's admissibility. The process of preparing and submitting available intelligence information to a court would significantly contribute to minimizing operational error that otherwise would occur.

\section{CONTENTS}

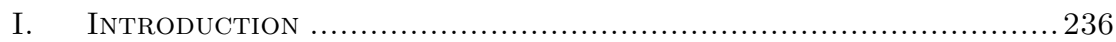

II. Fundamental Concepts ............................................ 241

A. Morality in Armed Conflict........................................... 241

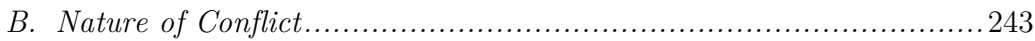

C. Role of Modern Technology............................................ 245

III. The Decision-Making Process ........................................245

A. The Importance of Process ......................................... 246

B. Who Are Legitimate Targets? ..................................... 248

C. Is the Intelligence Actionable? ......................................... 250

D. Is the Response Proportional? ........................................252

* Professor of Law, S.J. Quinney College of Law, University of Utah; author of LEgitimate TARget: A CRiteria-BASED APPROACH TO TARgeted Killing (Oxford Uni. Press, forthcoming). 
IV. The Drone Policy ................................................... 254

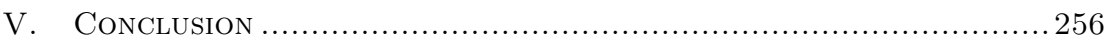

\section{INTRODUCTION}

Targeted killing sits at the intersection of law, morality, strategy, and policy. For the very reasons that lawful and effective targeted killing enables the state to engage in its core function of self-defense and defense of its nationals, I am a proponent of targeted killing. However, my support for targeted killing is conditioned upon it being subject to rigorous standards, criteria, and guidelines. My advocacy of both targeted killing and criteria-based decision-making rests largely on my twenty years of experience with a "seat at the table" of operational counterterrorism. The dangers inherent in the use of state power are enormous. On the opposite side of the equation, however, is the terrible cost of terrorism because terrorists, in deliberately targeting innocent civilians, disregard both legality and morality.

At present, new conceptions of threat and new technological capabilities are drastically affecting the implementation of targeted killing and the application of core legal and moral principles. Highlevel decision makers have begun to seemingly place a disproportionate level of importance on tactical and strategic gain over respect for a narrow definition of criteria-based legal and moral framework. ${ }^{1}$ Given the realities of collateral damage and other inevitable consequences, such an emphasis on tactical and strategic gain is troublesome. Nonetheless, an effective targeted killing provides the nation state with significant advantages in the context of counterterrorism.

The fine line that separates the competing needs for both an effective counterterrorism strategy and a governing legal and moral framework is paper thin. While success is undoubtedly seductive,

1. An earlier version of this article was published at e-International Relations. See Amos N. Guiora, Targeted Killing: The Limits of Power, e-International Relations (Sept. 4, 2012), http://www.e-ir.info/2012 /09/04/targeted-killing-the-limits-of-power/. Throughout this article I will refer to the "morality" or "moral framework" at issue in targeted killings. Proponents of targeted killings frequently rely on the legal, tactical, and strategic justifications and overlook the moral implications of targeted killings. In contrast, opponents of targeted killings frequently cite the morality - or lack thereof - as an argument against targeted killings. Those who support and order targeted killings need to look beyond the legal framework and confront the moral component of targeted killing policy. For an extensive report on the real-life impact of targeted killing, which might guide such an evaluation, see generally Stanford Int'l Hum. RTs. \& Conflict Res. Clinic \& NYU Global Justice Clinic, Living Under Drones: Death, Injury and Trauma to Civilians from U.S. Drone Practices in Pakistan (2012). 
DECISION M AKERS MUST CONSIDER THE RAMIHCATIONS OF A TARGEIED KIWNG GONE AWRY. THE SEEM INGLY SURGICAL PREAISION OF A DRONE ATTACK IS SO POWEREUL AND AWURING THAT IT HAS THE POIENTIAL TO BUND US FROM ITS POWEREUL AND COMPEWNG DOWNSIDES - AND FROM THE IEGAL AND MORAL FAIUURES THAT IT M AY WEUL SPAWN.

IN THE OURRENT ENVIRONMENT, THE INTERNATIONAL PRINGPIE OF PROPORIIONAITTY IS OUT OF PROPORIION. EXPANDED NOIIONS OF IM MINENCE, FEXIBLY AND BROADLY DEHNED, M ARRIED WITH INCREASING REUIANCE ON SIEEK NEW TECHNOLOGY, IE AT THE HEART OF RE-CONCEPTIONS OF PROPORIIONAITY CAPACIOUS ENOUGH TO ENCOM PASS NEARLY ALL TARGEIING DECISIONS.

THIS ESSAY, THE FOUNDATION OF WHICH IS MY EXPERENCE IN OPERATIONAL COUNTERIERRORISM, IS INTENDED TO BE A CAARON CALL PROPOSING THE UNITED STATES UNDERTAKE, IM MEDIATELY AND INTENSELY, A SIGNIFCANT RE-APPRAISAL OF ITS COUNTERIERRORISM POICY. THESE WORDS, WRTIEN IN AUGUST 2012, WERE UNFORIUNATELY PRESCIENT. WHEN I PENNED THEM, IT WAS NOT MY EXPECTATION U.S. DRONE POICY WOUID TAKE ON A DEEPLY TROUBUNG AND PROBIEM ATIC NATURE.

UNFORIUNATELY, THE RECENTIIY REIEASED DEPARIMENT OF JUSTICE WHITE PAPER $^{2}$ REGARDING THE OBAM A ADMINISTRATION'S DRONE POIICY RAISES PROFOUND CONCERNS REGARDING ITS IEGAITYY AND MORAITY. THE WHIE PAPER:

[S]EIS FORIH A IEGAL RAM EWORK FOR CONSIDERING THE CIROUMSTANCES IN WHICH THE U.S. GOVERNM ENT COUID USE IEIHAL FORCE IN A FOREIGN COUNTRY OUTSIDE THE AREA OF ACIIVE HOSTIITIES AGAINST A U.S. CTIZEN WHO IS A SENIOR OPERATIONAL IEADER OF ALQA'IDA OR AN ASSOCIATED FORCE OF ALQA'IDA - THAT IS, AN ALQA'IDA IEADER ACIIVELY ENGAGED IN PLANNING OPERATIONS TO KIL AM ERICANS. ${ }^{3}$

ACCORDING TO THE WHITE PAPER, THE UNITED STATES WOUID BE ABIE TO USE IEIHAL FORCE AGAINST A U.S. CITIZEN, WHO IS LOCATED OUTSIDE THE UNITED STATES AND IS AN OPERATIONAL IEADER CONTINUAIIY PLANNING ATTACKS AGAINST U.S. PERSONS AND INTERESTS, IN AT IEAST WHEN:

(1) AN INFORM ED, HIGH-IEVEL OFHCIAL OF THE U.S. GOVERNM ENT HAS DEIERM INED THAT THE TARGEIED INDIVIDUAL POSES AN IMMINENT THREAT OF VIOIENT ATTACK AGAINST THE UNITED STATES; (2) CAPTURE OPERATION IS INFEASIBIE-AND THE UNITED STATES CONTINUES TO M ONITOR WHEIHER CAPTURE BECOM ES FEASIBIE; AND (3) THE OPERATION

2. U.S. Dep't of Justice, Lawfulness of a Lethal Operation Directed Against a U.S. Citizen Who is a Senior Operational Leader of Al Qaida or an Associated Force (White Paper, undated), available at http:// msnbcmedia.msn.com/i/msnbc/sections/news/020413_DOJ_White_Pa per.pdf.

3. Id. at 1 . 
would be conducted in a manner consistent with applicable law of war principles. ${ }^{4}$

However, the White Paper dramatically broadens the definition of legitimate target:

[T]he condition that an operational leader present an "imminent" threat of violent attack against the United States does not require the United States to have clear evidence that a specific attack on U.S. persons and interests will take place in the immediate future. ${ }^{5}$

Experience tragically shows that when a "legitimate" target is broadly defined, significant collateral damage is inevitable. Needless to say, the grave dangers emanating from the White Paper raise deeply disturbing questions regarding the policy's legality, morality and effectiveness.

The DOJ white paper both harkens back to the Bush Administration's unitary executive theory and to the infamous Bybee Memo $^{6}$ that established the Bush Administration's torture regime. There is a powerful and disturbing link between the Obama Administration's drone policy and the Bush Administration's interrogation policy. When writing a previous book, Constitutional Limits of Coercive Interrogation, ${ }^{7} \mathrm{I}$ met with U.S. interrogators based in Iraq. Their most striking request was that guidelines and criteria regarding limits of interrogation be clearly articulated in detailed written instructions. Their "demand" was predicated on a deeply held conviction (with which I agreed) that the Bybee Memo established a paradigm best described as "by all means necessary" and grave concern their command structure would demand interrogation measures in violation of domestic and international law.

Re-articulated: experienced interrogators were convinced superiors, in accordance with the Bybee Memo, would demand they violate the law. By analogy, it is troubling, albeit reasonable, to presuppose the White Paper will result in actions that violate domestic and international law. Not because commanders are inherently prone to nor particularly relish committing crimes; nevertheless, the White Paper has created an unduly (and unfair) complicated dilemma for commanders and decision makers. The

4. $I d$.

5. Id. at 7 .

6. See Michael Scherer, Bush Torture Memo Approved Use of Insects, Time, Apr. 16, 2009, http://www.time.com/time/nation/article/0,8599, 1891812,00.html.

7. Amos N. Guiora, Constitutional Limits on Coercive Interrogation (Oxford Uni. Press, 2008). 
combination of defining legitimate target as "senior, Al-Qaeda operational leader" including U.S. citizens and an extraordinarily broad imminence definition creates a targeted killing paradigm akin to the interrogation excesses that followed in the wake of the Bybee Memo.

Given the excessive paradigm the white paper articulates one can only recall the ageless and immortal words of Justice Robert Jackson in Youngstown Sheet 85 Tube Co. v. Sawyer. ${ }^{8}$ While different context and distinct circumstances, Justice Jackson's powerful warning regarding the unfettered executive ring as loudly today as they did when penned. Perhaps, with all due deference both to Justice Jackson and the facts before the Supreme Court in Youngstown, the words must be heard louder today. The reason: the paradigm established by the DOJ white paper facilitates the potential harm to human lifeincluding U.S. citizens - by an unfettered executive determining whether an individual is a legitimate target devoid of process and review.

The unitary executive theory aggressively articulated, and implemented, by the Bush Administration has been adopted in toto by the Obama Administration. While the executive clearly prefers to operate in a vacuum, the question whether that most effectively ensures effective operational counterterrorism is an open question. The advantage of institutionalized, process-based input into executive action prior to decision implementation is worthy of discussion in operational counterterrorism.

The solution to this search for an actionable guideline is the strict scrutiny standard. What is strict scrutiny, and how is it to be implemented in the context of operational counterterrorism? Why is there a need, if at all, for an additional standard articulating selfdefense? The strict scrutiny standard would enable operational engagement of a non-state actor predicated on intelligence information that would meet admissibility standards akin to a court of law. The strict scrutiny test seeks to strike a balance enabling the state to act sooner but subject to significant restrictions.

The ability to act sooner is limited, however, by the requirement that intelligence information must be reliable, viable, valid, and corroborated. The strict scrutiny standard proposes that for states to act as early as possible in order to prevent a possible terrorist attack the information must meet admissibility standards similar to the rules of evidence. The intelligence must be reliable, material, and probative.

8. 343 U.S. 579, 637 (1952) ("When the President acts in absence of either a congressional grant or denial of authority, he can only rely upon his own independent powers, but there is a zone of twilight in which he and Congress may have concurrent authority, or in which its distribution is uncertain."). 
The proposal is predicated on the understanding that while states need to engage in operational counterterrorism, mistakes regarding the correct interpretation and analysis of intelligence information can lead to tragic mistakes. Adopting admissibility standards akin to the criminal law minimizes operational error.

Rather than relying on the executive branch making decisions in a "closed world" devoid of oversight and review, the intelligence information justifying the proposed action must be submitted to a court that would ascertain the information's admissibility. The discussion before the court would necessarily be conducted ex parte; however, the process of preparing and submitting available intelligence information to a court would significantly contribute to minimizing operational error that otherwise would occur.

The logistics of this proposal are far less daunting than they might seem - the court before which the executive would submit the evidence is the FISA Court. Presently, FISA Court judges weigh the reliability of intelligence information in determining whether to grant government ex parte requests for wire-tapping warrants. Under this proposal, judicial approval is necessary prior to undertaking a counterterrorism operation predicated solely on intelligence information. The standard the court would adopt in determining the information's reliability is the same applied in the traditional criminal law paradigm. The intelligence must be reliable, material, and probative.

While the model is different - a defense attorney cannot question state witnesses - the court will assume a dual role. In this dual role capacity the court will cross-examine the representative of the intelligence community and subsequently rule as to the information's admissibility. While some may suggest that the FISA court is largely an exercise in "rubber-stamping," the importance of the proposal is in requiring the government to present the available information to an independent judiciary as a precursor to engaging in operational counterterrorism.

The call is complicated: the United States is a nation based on democratic values rooted in ethics and morals; yet, when push comes to shove the United States does not always act in accordance with these articulated principles. The vision of a "city upon a hill," articulated by Puritan settler John Winthrop and subsequently referenced by President Ronald Reagan, ${ }^{9}$ has been called into question by certain U.S. counterterrorism measures. This is not the first time

9. See President Ronald Reagan, Farewell Address to the Nation (Jan. 11, 1989), available at http://www.reagan.utexas.edu/archives/speeches/19 89/011189i.htm. 
that American responses in the face of crisis (whether real or perceived) have reflected "over-board" and "over-broad" approaches. ${ }^{10}$

Although targeted killing is applied in a wide array of circumstances and locations, such as Afghanistan, it is the use of targeted killings as self-defense against individuals deemed as posing a direct threat to national security ${ }^{11}$ that raises a significantly broader and more complex set of considerations, extending beyond the law of armed conflict and its application. U.S. counterterrorism policy, and targeted killing strategy in particular, highlights a number of important issues: 1) a failure to articulate threats in a manner that defines and operationalizes imminence in a careful, effective, and moral way; 2) an over-reliance on technology in intelligence-gathering and potentially intelligence analysis; 3) ends-based decision making rather than decision making based on morality and law; and 4) a failure to develop and use a process to move from the articulation of a threat to the lethal targeting decision in a discriminating, moral, and law-based manner.

\section{Fundamental Concepts}

\section{A. Morality in Armed Conflict}

One of the dominant, and admittedly controversial, arguments this essay advances is that states have an obligation to conduct themselves morally, including during armed conflict. Although some may find this notion inherently contradictory, "morality in armed conflict" is a term of art (and not an oxymoron) that lies at the core of the instant discussion. This concept imposes an absolute requirement that soldiers treat the civilian population of areas in which they are engaged in conflict with the utmost dignity and respect. This obligation holds true whether combat takes place "house-to-house" or using remotely piloted aircraft tens of thousands of feet up in the sky. This concept may be simple to articulate, yet it is difficult to implement; the operational reality of armed conflict short of war requires a soldier to make multiple decisions involving various factors, all of which have never-ending spin-off potential. After all, every decision is not only complicated in and of itself, but

10. See, e.g., Amy Zegart, Taking Resilience Too Far, Slate (Mar. 19, 2012), http://www.slate.com/articles/technology/future_tense/2012/03 /reilience_in_national_security_is_overrated_.html.

11. See Harold Hongju Koh, Legal Adviser, U.S. Dep't of State, Speech at the Annual Meeting of the American Society of International Law (Mar. 25, 2010), available at http://www.state.gov/s/l/releases/remarks/1391 19.htm; Eric Holder, Att'y Gen., U.S. Dep't of Just., Speech at Northwestern University School of Law (Mar. 5, 2010), available at http://www.justice.gov/iso/opa/ag/speeches/2012/ag-speech-1203051 .html. 
each operational situation has a number of "forks." The implication is that no decision is linear, and every decision leads to additional dilemmas and spurs further decision making.

Operational decision-making is thus predicated on a complicated triangle that must incorporate the rule of law, morality, and effectiveness. I have been asked repeatedly whether that triangle endangers soldiers while giving the "other side" an undue advantage. The concern is understandable; however, the essence of armed conflict is that innocent civilians are in the immediate vicinity of combatants, and there is a duty to protect them even at the risk of harm to soldiers. ${ }^{12}$ The burden to distinguish between combatant and civilian is extraordinarily complicated and poses significant operational dilemmas for and burdens on soldiers.

For armed conflict conducted in accordance with the rule of law and morality, this burden of distinction can never be viewed as mere mantra. Distinction, ${ }^{13}$ then, is integral to the discussion. It is as relevant and important to the soldier standing at a check-point, uncertain whether the person standing opposite him is a combatant or civilian, as it must be in any targeted killing dilemma. The decision whether to operationally engage must reflect a variety of criteria and guidelines. ${ }^{14}$ Otherwise, the nation state conducts itself in the spirit of a video game where victims are not real and represent mere numbers, regardless of the degree of threat they pose.

At the most fundamental level, operational decision making in the context of counterterrorism involves the decision whether to kill an individual defined as a legitimate target. ${ }^{15}$ Although some argue killing is inherently immoral, I argue that killing in the context of narrowly defined self-defense is both legal and moral provided that the decision to "pull the trigger" is made in the context of a highly circumscribed and criteria-based framework. If limits are not imposed in defining a legitimate target, then decisions take on the hue of both illegality and immorality.

12. See generally Geneva Convention Relative to the Protection of Civilian Persons in Time of War, Aug. 12, 1949, 6 U.S.T. 3516, 75 U.N.T.S. 287.

13. See, e.g., Declaration Renouncing the Use, in Time of War, of Certain Explosive Projectiles, Nov. 29-Dec. 11, 1868, 18 Martens Nouveau Recueil (ser. 1) 474, 138 Consol. T.S. 297 (declaring "[t]hat the only legitimate object which States should endeavour to accomplish during war is to weaken the military forces of the enemy").

14. See Amos N. Guiora, Determining a Legitimate Target: The Dilemma of the Decisionmaker, 47 TEx. InT'L L.J. 315, 332-36 (2012).

15. See id. at 336 . 


\section{B. Nature of Conflict}

We are at a crossroads: traditional state war has morphed, by force of circumstances, into conflict between states and non-state actors. Traditionally, international law sought to establish criteria and limits by which nation states fought wars against other states, although violations of the laws of war inevitably occurred. ${ }^{16}$ Nevertheless, the rules were clearly articulated and understood, although not always implemented or respected. ${ }^{17}$ The era of state versus non-state conflict, in contrast, has been marked by both random and deliberate attacks against innocent civilians by non-state actors. ${ }^{18}$

The state, in response, has been forced to develop and implement operational counterterrorism measures intended to protect the civilian population while striking at those responsible for the attacks. Such response has been legitimate and necessary. The primary obligation of the state is to protect its innocent civilian population and valuable national resources and assets. ${ }^{19}$ While this obligation is unambiguous, the question remains: how can a state meet these obligations? Should there be limits imposed regarding the use of force? And if so, what are those limits?

It is unfortunately easy in the face of terrorism to take an expansive view regarding self-defense and the definition of legitimate target. That "ease" is magnified in the immediate aftermath of an attack when the public, media, and politicians are clamoring for aggressive responses to strike at those responsible, and to deter those considering future acts of terrorism. ${ }^{20}$ The rhetoric in the United States immediately after 9/11 demonstrates how such calls for aggressive responses to terrorism play out. Former-U.S. Attorney General Alberto Gonzales' disdainful description of international law

16. See, e.g., Hague Convention Respecting the Laws and Customs of War on Land and Its Annex, Oct. 18, 1907, 36 Stat. 2277, T.S. No. 539

17. See Guiora, supra note 14 , at 320 .

18. See generally UN Global Counter-Terrorism Strategy, G.A. Res. 60/288, U.N. Doc. A/RES/60/288 (Sept. 20, 2006). See also Richard A. Oppel Jr. \& Taimoor Shah, Differing Theories in Killing of 17 in Taliban Stronghold, N.Y. Times, Aug. 27, 2012, at A8 (discussing attacks on civilians by non-state actors).

19. UN Global Counter-Terrorism Strategy, supra note 18 (noting the threat non-state actors can pose to state security through acts of terrorism).

20. See How 9/11 Changed How Americans View the World, NPR (Sept. 10, 2012), http://www.npr.org/2012/09/10/160886676/how-9-11-chang ed-how-america-sees-the-world (discussing the often vast difference between public opinion immediately after a crisis and public opinion further removed from the crisis). 
as "quaint" 21 was matched only by former-Vice President Richard Cheney's reference to water-boarding as a mere "dunk in the water." 22 The result was an operational counterterrorism model predicated on lawlessness and state power subject neither to the rule of law nor morality. From the perspective of the "boots on the ground," there is extraordinary danger when national decision makers adopt a paradigm best described as lawless.

The concern for a moral and legal basis in conflict and counterterrorism operations is not based on compassion for terrorists. Anyone who deliberately targets innocent men, women, and children is a legitimate target. ${ }^{23}$ However, decision making subject to moral and legal restraints must go beyond an indiscriminate application of power that is devoid of articulated and narrowly applied criteria. Although collateral damage may well be inevitable to war and counterterrorism alike, it is nevertheless essential that states recognize their absolute obligation to proactively minimize the deaths of innocent individuals.

That burden is unduly impacted by the callous decision by nonstate actors to deliberately place their innocent civilians in harm's way. Human shielding is a clear violation of international law and reflects extraordinary disregard for the value of human life. ${ }^{24}$ As made clear during Operation Cast Lead (i.e., the Gaza War), ${ }^{25}$ terrorist organizations deliberately use their own civilians as human shields. ${ }^{26}$ However, that fact does not and must not justify targeted killing that

21. John D. Hutson \& Heather MacDonald, Should Gonzales Be Attorney General?, LEGAL AfF. (Jan. 25, 2005, 10:27 AM), http://www.legalaffa irs.org/webexclusive/debateclub_gonzales0105.msp.

22. See Snow: Cheney Doesn't Support 'Water Boarding,' Associated Press (Oct. 27, 2006), http://www.msnbc.msn.com/id/15443701/ns/p olitics/t/snow-cheney-doesnt-support-water-boarding/\#.UIdaRUI1ZSW.

23. See Charli Carpenter, Fighting the Laws of War, Foreign AfF., Mar.Apr. 2011, at 146 (discussing the challenges posed by modern warfare, but concluding that traditional laws of war, including those that prohibit targeting innocent civilians, still apply).

24. See generally Michael N. Schmitt, Human Shields in International Humanitarian Law, 47 Colum. J. Transnat'L L. 292 (2009).

25. See Israel Says Gaza Death Toll Lower Than Claimed, CNN (Mar. 26, 2009), http://articles.cnn.com/2009-03-26/world/israel.gaza.death.toll_1 israeli-military-palestinians-civilian-deaths? $\mathrm{s}=\mathrm{PM}: \mathrm{WORLD}$ (discussing Operation Cast Lead).

26. See Terrorists Use Palestinian Civilians As Human Shields (Info Live television broadcast Jan. 1 2010), available at http://www.youtube. com/watch?v=n_YP6AtdwJQ\&feature=fvwrel; see also Cast Lead Video: Hamas Terrorist Uses Children as Human Shield, (Israeli Def. Forces online video Sept. 17, 2009), http://www.youtube.com/watch $? \mathrm{v}=2 \mathrm{vHDyuSTneA}$. 
results in undue collateral damage. The fact that terrorist organizations violate standards of law and morality must be universally condemned, but such conduct does not justify a paradigm in which collateral damage is tolerated. Ethical decision making, human judgment, a moral conscience, and the rule of law must all work together to ensure that Americans do not become the enemy we are fighting. ${ }^{27}$

\section{Role of Modern Technology}

The use of drones, also known as unmanned aerial vehicles (UAV), has further complicated the relationship between counterterrorism, self-defense, and morality in armed conflict. Many argue that the combination of modern technology and sophisticated intelligence analysis all but ensures that UAV policy is the most effective contemporary means to conduct operational counterterrorism. ${ }^{28}$ The argument sounds compelling and convincing: what is more attractive than killing terrorists from the air with the use of sleek technology while minimizing risk to ground forces? We are in an age where shiny technology and seemingly sophisticated intelligence gathering and analysis converge, potentially removing the human element, and humanity, from decision making. ${ }^{29}$ However, targeted killing is fraught with extraordinary risk. Computers and advanced technology are, undoubtedly, essential to intelligence gathering and other important aspects of counterterrorism and armed conflict; suggesting otherwise would be folly. But the trend towards relaxed or flexible definitions of imminence, legitimate targets, and proportionality means that such an increasing reliance on technology can exacerbate rather than curtail these dangers.

\section{The Decision-Making Process}

The Obama Administration articulated a broad rationale for the Anwar al-Awlaki killing, based on the theory of aggressive selfdefense. ${ }^{30}$ More recently, the administration has acknowledged the broader drone program, again defending it as lawful:

27. My gratitude to Margaret $\mathrm{Hu}$ for articulating this point so clearly for me.

28. See, e.g., Laurie R. Blank, After "Top Gun": How Drone Strikes Impact the Law of War, 33 U. PA. J. INT'L L. 675, 679, 701 (2011) (discussing the potential impact of unmanned drones on the law of armed conflicts).

29. David E. SAnger, Confront And Conceal 244 (2012) (reporting a top Obama Administration official's concern that new technology distracts from human realities).

30. John O. Brennan, Assistant to the President for Homeland Security and Counterterrorism, Strengthening Our Security by Adhering to Our Values and Laws, Address at Harvard Law School (Sept. 16, 2011), 
In practice, the U.S. approach to targeting in the conflict with al-Qa'ida is far more aligned with our allies' approach than many assume. This Administration's counterterrorism efforts outside of Afghanistan and Iraq are focused on those individuals who are a threat to the United States, whose removal would cause a significant - even if only temporary - disruption of the plans and capabilities of al-Qa'ida and its associated forces. Practically speaking, then, the question turns principally on how you define "imminence." ${ }^{31}$

We are finding increasing recognition in the international community that a more flexible understanding of "imminence" may be appropriate when dealing with terrorist groups, in part because threats posed by non-state actors do not present themselves in the ways that evidenced imminence in more traditional conflicts. After all, al-Qa'ida does not follow a traditional command structure, wear uniforms, carry its arms openly, or mass its troops at the borders of the nations it attacks. Nonetheless, it possesses the demonstrated capability to strike with little notice and cause significant civilian or military casualties. Over time, an increasing number of our international counterterrorism partners have begun to recognize that the traditional conception of what constitutes an "imminent" attack should be broadened in light of the modern-day capabilities, techniques, and technological innovations of terrorist organizations.

\section{A. $\quad$ The Importance of Process}

Effective counterterrorism requires the state to apply self-imposed restraint, otherwise violations of both international law and morality in armed conflict are all but inevitable. The manner in which a counterterrorism operation is carried out will determine its legality under governing international instruments. Among the many important international law principles applicable to targeted killing, the obligation of distinction sits at the pinnacle. The notion of counterterrorism as self-defense against imminent threats from terrorist or other non-state actors means that the state must know, in a detailed manner, who poses such a threat, in what circumstances, and how and when such person can be targeted. ${ }^{32}$ This information

available at http://www.whitehouse.gov/the-press-office/2011/09/16/re marks-john-o-brennan-strengthening-our-security-adhering-our-valuesan.

31. Id

32. This section builds off a previous article, see Laurie Blank \& Amos Guiora, Targeted Killing's 'Flexibility' Doctrine that Enables US to Flout the Law of War, The GuARDian (UK) Aug. 10, 2012, http://www.guardian.co.uk/commentisfree/2012/aug/10/targetedkilling-flexibility-doctrine-flout-law-war. 
and analysis lies at the heart of the legitimate target determination. Next, the state (that is, those making decisions regarding targeted strikes) must undertake the necessary proportionality analysis: will civilians be harmed and if so, how many? In an effort to successfully minimize the number of innocent civilians killed during conflict (usually referred to by the unfortunate term "collateral damage"), the attacking party must refrain from any attacks where the expected civilian casualties will be excessive in relation to the anticipated military advantage gained. ${ }^{33}$

In the end then, the lawfulness of targeted killing depends, in large part, on the efficacy of the internal administrative measures adopted to identify targets. ${ }^{34}$ Only when those procedures are effective and discriminating will targeted killing be both legal and moral. Why? Because targeted killing is not about encountering a division of the enemy's forces on the battlefield and stopping it from advancing across the front towards your borders or essential infrastructure. Such are the tactics of traditional conflict, of trench warfare, and tank warfare in state versus state conflict. Targeted killing rests on the specific identification of individuals who pose an imminent threat to the state's national security and are, therefore, legitimate targets within the framework of lawful self-defense. ${ }^{35}$ The state thus needs a method and a process for figuring out who poses a threat, why they pose a threat, and how that threat can be deterred or eliminated. Understanding more clearly what precisely those targeting procedures are is an important first step. Therefore, in any targeted killing decision, the following important questions must be addressed:

\begin{tabular}{|l|l|}
\hline $\begin{array}{l}\text { 1. Can the target be identified } \\
\text { accurately and reliably? }\end{array}$ & $\rightarrow$ Is the target legitimate? \\
\hline $\begin{array}{l}\text { 2. Does the target pose a threat such } \\
\text { that an attack on the target at that } \\
\text { moment is justified or are there } \\
\text { alternatives available? }\end{array}$ & $\begin{array}{l}\text { actionable? } \\
\text { actelligence }\end{array}$ \\
\hline $\begin{array}{l}\text { 3. What is the anticipated extent of } \\
\text { collateral damage? }\end{array}$ & $\begin{array}{l}\text { ( Is the response } \\
\text { proportional? }\end{array}$ \\
\hline
\end{tabular}

33. See Gabriella Blum \& Philip Heymann, Law and Policy of Targeted Killing, 1 HARV. NAT'L SEC. J. 145, 148 (2010) (comparing targeted killing in international war and proportionality concerns to US domestic law enforcement and related principles of proportionality).

34. Blank \& Guiora, supra note 32 .

35. See Amos Guiora, Targeted Killing as Active Self Defense, 36 CASE W. RES. J. INT'L L. 320, 325 (2004). 
To answer these questions legally, morally, and effectively, decision makers must use a criteria-based process. Criteria-based decision making increases the probability of correctly identifying and attacking a legitimate target while minimizing collateral damage, thereby enhancing the policy's effectiveness. The criteria-based process is dependent upon the gathering of intelligence information from three separate sources: human intelligence; signal intelligence; and open-source information. ${ }^{36}$ Intelligence analysts then determine whether the information is actionable.

\section{B. Who Are Legitimate Targets?}

The foundation for determining the legality of targeted killing is assessing whether the threat's imminence justifies the action in order to protect an innocent civilian population. ${ }^{37}$ In order to implement legal, moral, and effective operational counterterrorism, decision makers must initially evaluate the threat. This evaluation must include the following:

\begin{tabular}{|c|c|c|c|}
\hline $\begin{array}{c}\text { Analysis of } \\
\text { the threat's } \\
\text { nature }\end{array}$ & $\begin{array}{c}\text { Identifying the } \\
\text { threat's source }\end{array}$ & $\begin{array}{c}\text { Identifying the } \\
\text { timeline when } \\
\text { the threat is } \\
\text { anticipated to } \\
\text { materialize }\end{array}$ & $\begin{array}{c}\text { Assessment of } \\
\text { the threat's } \\
\text { imminence }\end{array}$ \\
\hline
\end{tabular}

The suicide bomber infrastructure is instructive in highlighting the complexities of determining whether an individual is a legitimate target; it is important to recall that four distinct actors are necessary for a successful suicide bombing:

36. See Thomas S. Szayna et al., Improving Army Planning for Future Multinational Coalition Operations 324 (2001).

37. See Mark L. Rockefeller, The "Imminent Threat" Requirement for the Use of Preemptive Military Force: Is it Time for a Non-Temporal Standard?, 33 DenV. J. InT'L L. \& POL'Y 131, 131 (2005) (discussing the imminence standard). 


\section{TARGET - The Suicide Bombing Infrastructure}

a) Planner - legitimate target at all times

b) Bomber - legitimate target solely when operationally engaged

c) Logistician-legitimate target when involved in all aspects of implementing suicide bombing but, unlike the planner, not a legitimate target when not involved in a specific, future attack

d) Financier - a largely unexplored subject in the context of targeted killings, the financier is a legitimate target when involved in wiring or laundering money, both of which are essential for terrorist attacks. There is significant room for debate regarding when the financier is not in the act of financing. To that extent, the question is whether the financier is more akin to the "bomber" or the "logistician." Arguably, due to the central role the financier plays in the structure, the correct placement is between the "logistician" and the "planner."

Imminence must be understood from two distinct perspectives: the imminent threat posed by the bomber and the future threat posed by a planner or financier considered legitimate targets, even when not directly engaged in planning or implementing a suicide bombing. In order for a state's actions under either scenario to be considered legal, the limits of self-defense must be defined. The policy of targeted killing should only be used in response to imminent threats rather than those that are distant, unviable, or merely foreseeable. ${ }^{38}$

38. Jameel Jaffer, Targeted Killing and the Courts: A Response to Alan Dershowitz, 37 Wm. Mitchell L. Rev. 5315, 5317 (2011) (discussing the imminence requirement for lethal force). 
Targeted killings based on vague threats are grounded in revenge and emotion rather than in objective, criteria-based decision making. Put simply, a legitimate target is an individual who, according to intelligence information, poses a direct and immediate threat to national security. Here, the notion of proportionality in self-defense is operationalized in the plainest manner-the decision maker must determine whether lethal force is the appropriate response to the threat posed in order to repel or deter that imminent threat. It is important, therefore, to recognize that as definitions of imminence become broader and more flexible, the parameters of that proportionality analysis stretch as well. ${ }^{39}$

\section{Is the Intelligence Actionable?}

Threat analysis refers to the nature of the target and his or her planned activities and attacks. ${ }^{40}$ Assessing the source of the information about the target and the planned attack is an equally vital aspect of the decision-making process. Information provided by a human source should be analyzed closely for possible biases, grudges, or personal agendas that might taint its reliability. Therefore, source analysis becomes a fundamental component of the criteria-based approach. Signal intelligence includes information gathered from sources such as intercepted phone and email conversations. ${ }^{41}$ Open sources, such as the internet and newspapers, are generally available and can often help paint a landscape against which a perceived threat can be evaluated. The combination of these three sources allows the intelligence community to develop an accurate operational picture from which to work. In this information gathering process, the intelligence produced from UAV reconnaissance is highly valuable, particularly with regard to tracking targets and ensuring that the person under analysis is actually the person who poses the threat. But this type of intelligence alone simply cannot be a substitute for the complex web of information and analysis woven together using all three sources of intelligence described above. It is essential, therefore, to guard against over-reliance on the extraordinary capabilities of modern technology.

39. Cf. Benjamin McKelvey, Due Process Rights and the Targeted Killing of Suspected Terrorists: The Unconstitutional Scope of Executive Killing Power, 44 VAnd. J. Transnat'L L. 1353, 1368 (2011) (noting that the imminence standard becomes useless if the decision-maker must go through months of evaluation).

40. Amos Guiora \& Monica Hakimi, Targeted Killing is Lawful if Conducted in Accordance with the Rule of Law, ABA LAW J., Apr. 1, 2012, http://www.abajournal.com/magazine/article/targeted_killing_is_lawf ul_if_conducted_in_accordance_with_the_rule_of_law.

41. See Signals Intelligence, NAt'L Security Agency Cent. Security SERV., http://www.nsa.gov/sigint/index.shtml (last updated Sept. 9, 2011). 
Ultimately, the question central to this operational puzzle is whether the acquired information is actionable. The main goal of decision makers is to enhance the objectivity in their decision-making process. The chart below, developed to evaluate detention decisions, is an example of articulated guidelines for determining whether the intelligence is sufficiently actionable.

\begin{tabular}{|l|c|}
\hline Test Prong & Definition/ Use \\
\hline Reliable & $\begin{array}{l}\text { Past interactions show the source to be } \\
\text { dependable provider of correct information }\end{array}$ \\
$\square$ Determination as to whether the \\
information is useful and accurate \\
$\square \begin{array}{l}\text { Requires analysis by case officer into } \\
\text { source's personal agendas or grudges with } \\
\text { respect to identified target }\end{array}$ \\
$\square \begin{array}{l}\text { Is it possible that an attack could occur in } \\
\text { accordance with the source's information } \\
\text { (Based on source's information, such a } \\
\text { terrorist attack is both possible and } \\
\text { feasible) }\end{array}$ \\
$\square$ Relevant \\
$\square \begin{array}{l}\text { The information has bearing on upcoming } \\
\text { events } \\
\text { Consider both timeliness of the information } \\
\text { and whether it is time sensitive, thereby } \\
\text { imposing the need for immediate } \\
\text { counterterrorism measures }\end{array}$ \\
\hline
\end{tabular}




\begin{tabular}{|l|l|}
\hline Corroborated & $\square \begin{array}{l}\text { Another source confirms the information in } \\
\text { part or whole }\end{array}$ \\
$\square \begin{array}{l}\text { This second source must also meet the } \\
\text { above reliability test }\end{array}$ \\
\hline
\end{tabular}

\section{Is the Response Proportional?}

Even if a legitimate target is identified and the intelligence about that target is actionable, the use of lethal force, in this case a targeted killing, is lawful only if it meets the international law obligation of proportionality. ${ }^{42}$ As noted above, an attack violates the principle of proportionality if the expected civilian casualties will be excessive in relation to the military advantage gained. ${ }^{43}$ Proportionality is a difficult concept to apply in any conflict situation, but it is absolutely essential for the protection of the civilian population. ${ }^{44}$ This analysis requires intelligence not just about the target of the attack, but also about who and what else is in the area and is likely to be killed, injured, or destroyed (when dealing with property) as a result of the attack. $^{45}$ It also requires a complete evaluation of significance of reaching the target. ${ }^{46}$

Of the principles discussed, proportionality receives the greatest attention and is the most scrutinized. ${ }^{47}$ It is also, I would suggest, the most problematic, most misconstrued, and least attainable. Proportionality is not about equality of capability or power of the two sides. State versus non-state conflict is inherently disproportionate.

42. Jean-Marie Henckaerts \& Louise Doswald-Beck, Customary InTERnAtional HUMANitarian LAW: Rules 46 (3d prtg. 2009) ("Launching an attack which may be expected to cause incidental loss of civilian life, injury to civilians, damage to civilian objects, or a combination thereof, which would be excessive in relation to the concrete and direct military advantage anticipated, is prohibited.").

43. See supra note 26 and accompanying text.

44. See W.J. Fenrick, The Law Applicable to Targeting and Proportionality After Operation Allied Force: A View from the Outside, in YEARBOOK OF INTERNATIONAL HumanitaRian LAW 58 (2000).

45. See id. at 75 .

46. See id.

47. See Enzo Cannizzaro, The Role of Proportionality in the Law of International Countermeasures, 12 EuRO. J. INT'L L. 889, 889 (2001). 
History is replete with examples of disproportionate warfare between states, much less between states and non-state actors. War is often won in large part by the use of significant, indeed overwhelming or disproportionate, force in order to defeat the other military. Proportionality seeks to minimize harm to the civilian population within the context of conflict, not to equalize the capabilities of warring states.

In the person-specific operational counterterrorism model, however, the legal principle of proportionality in self-defense is also a significant component of the legal decision-making process. Here, proportionality means that state action, proactive and reactive alike, must be proportional to the threat posed, whether actual or perceived, because in each specific instance, the state is using, and justifying the use of, force in self-defense. ${ }^{48}$ Operationalized, the term means the commander must be very selective both with respect to force used and individuals targeted. ${ }^{49}$

It is precisely at this confluence of legal principles and decision making that proportionality has become out of proportion in the framework of the U.S. targeted killing program. International law requires that targeting an individual with lethal force as self-defense can only be undertaken when the threat posed is such as to require the use of force to mitigate or eliminate the threat; that is, the use of force is proportional to the threat and the need to deter it. ${ }^{50}$ At the same time, international law also requires that the commander take into account the likely civilian harm and refrain from any attack where the expected collateral damage (civilian harm) is excessive given the value gained by killing the targeted individual. ${ }^{51}$

As the discussion below will highlight, the increasingly flexible and broad notion of imminence and threat have significant effects on the notion of "military advantage gained" (i.e., the value of the target) and therefore on the application of the proportionality principle governing the minimization of civilian harm. ${ }^{52}$ If all threats

48. See Fenrick, supra note 44, at 58 (stating that "there must be an acceptable relation between the legitimate destructive effect and undesirable collateral effects").

49. Id. at 75 .

50. See Blum \& Heymann, supra note 33, at 146 (stating that targeted killings are allowed only in limited circumstances such as self-defense when the person poses an immediate threat).

51. See Laurie Blank \& Amos Guiora, Teaching an Old Dog New Tricks: Operationalizing the Law of Armed Conflict in New Warfare, 1 HARV. NAT'L SEC. J. 45, 71 (2010) ("Whether a commander chooses to engage will depend on whether the person poses a threat at that moment and the likelihood of mission success.").

52. See infra Part IV. 
are so imminent and dangerous as to justify the use of lethal force in self-defense, then the value of taking them out will be great enough to justify significant amounts of civilian harm - essentially meaning that broad understandings of the first concept of proportionality eliminate the need for the second, equally essential, proportionality analysis. The result: a targeted killing policy not grounded in sufficient legal and moral footing.

\section{The Drone Policy}

The U.S. drone policy raises profoundly important questions regarding the very nature of operational counterterrorism; its implementation reveals how morality and the rule of law are applied in an inherently ambiguous and amorphous paradigm. At present, the increasingly broader and more flexible definition of imminence, combined with a continually growing reliance on sleek new technology, is highly problematic and raises significant concerns about whether law and morality are truly serving as the necessary guiding force here. Law not only provides a state with the right to engage those who deliberately and randomly target innocent civilians - it also provides the essential guiding framework for the extent to which and manner by which the state can target and engage those individuals. Simply articulating an aggressive, tough on terrorism policy is not sufficient. Rather, the devil truly is in the details: the state must carefully define both the limits of force and how that limited force is to be applied. Such a carefully-defined limit and application of force is the essence of both morality in armed conflict and the rule of law. In contrast, deliberately operating in an open-ended paradigm with opaque parameters where state power is broadly defined and implemented opens the door, unnecessarily, to significant violations of morality and law.

Unlimited drone warfare where limits, targets, and goals are not narrowly defined creates an operational environment in which anyone killed, regardless of whether intended or unintended, is considered a legitimate target. This expanded articulation of legitimate target, premised on significant expansion of tolerable collateral damage, creates a slippery slope that inevitably results in the deaths of otherwise innocent individuals. The allure of modern technology has led many decision makers to minimize the need to carefully distinguish between the individuals who pose a threat and those who do not.

Decision makers must not lose sight of the fact that targeted killing, on the basis of received and actionable intelligence information, is inherently a problematic; it poses extraordinary operational challenges that must be resolved precisely because of targeted killing's importance to lawful self-defense. It must be operationalized in the most careful, narrow, and specific manner possible-meaning that a discriminating analysis of who is a 
legitimate target must be matched by equally discriminating analysis of who constitutes collateral damage, how much collateral damage is likely, and, most important, how much collateral damage is legally and morally acceptable or tolerable.

Morality in armed conflict is not a mere mantra: it imposes significant demands on the nation state that must adhere to limits and considerations beyond simply killing "the other side." For better or worse, drone warfare of today will become the norm of tomorrow. Multiply the number of attacks conducted regularly in the present and you have the operational reality of future warfare. It is important to recall that drone policy is effective on two distinct levels: it takes the fight to terrorists directly involved, either in past or future attacks, and serves as a powerful deterrent for those considering involvement in terrorist activity. ${ }^{53}$ However, its importance and effectiveness must not hinder critical conversation, particularly with respect to defining imminence and legitimate target. The overly broad definition, "flexible" in the Obama Administration's words, ${ }^{54}$ raises profound concerns regarding how imminence is applied. That concern is concrete for the practical import of Brennan's phrasing is a dramatic broadening of the definition of legitimate target. It is also important to recall that operators - military, CIA or private contractors - are responsible for implementing executive branch guidelines and directives. ${ }^{55}$ For that very reason, the approach articulated by Brennan on behalf of the administration is troubling.

This approach, while theoretically appealing, fails on a number of levels. First, it undermines and does a profound injustice to the military and security personnel tasked with operationalizing defense of the state, particularly commanders and officers. When senior leadership deliberately obfuscates policy to create wiggle room and plausible deniability, junior commanders (those at the tip of the spear, in essence) have no framework to guide their operational choices. ${ }^{56}$ The results can be disastrous, as the example of Abu Ghraib shows all too well. ${ }^{57}$ Second, it gravely endangers the civilian population. What is done in the collective American name poses

53. See Ryan J. Vogel, Drone Warfare and the Law of Armed Conflict, 39 DENV. J. INT'L L. \& POL'Y 101, 107-09 (2010) (explaining the geographic expansiveness of drone policy and its use to prevent future attacks).

54. Brennan, supra note 30.

55. See Targeting Operations with Drone Technology: Humanitarian Law Implications 25 (Background Note for the Am. Soc'y of Int'l L. Annual Meeting, Hum. Rts. Inst., \& Colum. L. Sch., Mar. 25, 2011).

56. See Amos N. Guiora \& Martha Minow, National Objectives in the Hands of Junior Leaders, in COUNTERING TERRORISM AND INSURGENCY IN The 21st CENTURY 179, 184-85 (James J. F. Forest, ed., 2007).

57. See id. at 184 . 
danger both to our safety, because of the possibility of blow-back attacks in response to a drone attack that caused significant collateral damage, and to our values, because the policy is loosely articulated and problematically implemented. ${ }^{58}$ Third, the approach completely undermines our commitment to law and morality that defines a nation predicated on the rule of law. If everyone who constitutes "them" is automatically a legitimate target, then careful analysis of threats, imminence, proportionality, credibility, reliability, and other factors become meaningless. Self-defense becomes a mantra that justifies all action, regardless of method or procedure.

Accordingly, the increasing reliance on modern technology must raise a warning flag. Drone warfare is conducted using modern technology with the explicit assumption that the technology of the future is more sophisticated, more complex, and more lethal. Its sophistication and complexity, however, must not be viewed as a holy grail. While armed conflict involves the killing of individuals, the relevant questions must remain who, why, how, and when. Seductive methods must not lead us to reflexively conclude that we can charge ahead. Indeed, the more sophisticated the mechanism, the more questions we must ask. Capability cannot substitute for process and technology cannot substitute for analysis.

\section{CONCLUSION}

The state's right to engage in preemptive self-defense must be subject to powerful restraints and conditions. A measured, cautious approach to targeted killing reflects the understanding that the state has the absolute, but not unlimited, right and obligation to protect its civilian population.

Targeted killing is a legal, legitimate, and effective form of active self-defense provided that it is conducted in accordance with international law, morality, and a narrow definition of legitimate target. Self-defense, according to international law, is subject to limits; otherwise, administration officials would not press for flexibility in defining imminent. The call for a flexible conception of imminence is a deeply troubling manifestation of a "slippery slope;" it opens the door to operational counterterrorism not conducted in accordance with international law or principles of morality. Therefore, analyzing the reliability of intelligence, assessing the threat posed, and determining whether the identified target is a legitimate target facilitates lawful, moral, and effective targeted killing.

58. See $i d$. (discussing the illustrative "black flag" incident in which fifty-six innocent Israeli civilians were killed after junior leaders mistakenly interpreted a commanding officer's comment that God should have "mercy" on any villager out after curfew to be a command to shoot anyone returning from the fields after curfew). 
Expansiveness and flexibility are at odds with a measured approach to targeted killing precisely because they eliminate our sense of what is proportional, in the broadest sense of the term. Flexibility with regard to imminence and threat-perception means that the identification of legitimate targets, the true essence of moral operational counterterrorism, becomes looser and less precise. In turn, broader notions of legitimate target and the right of self-defense introduce greater flexibility with regard to collateral damage resulting in a wider understanding of who constitutes collateral damage and how much collateral damage is justified in the course of targeting a particular threat. Flexibility and the absence of criteria, process, and procedure result in notions of proportionality - which would normally guide decision making and operations - that are out of proportion. In the high-stakes world of operational counterterrorism, there is no room for imprecision and casual definitions; the risks, to innocent civilians on both sides and to our fundamental values, are just too high.

With respect to the strict scrutiny standard and recommendation for establishment of a "drone court": while the proposal explicitly calls for changing the nature of the relationship between the executive and the judicial branches of the government, it would serve to minimize intelligence-based mistakes in operational counterterrorism. To ensure enforcement, a president that acts in contravention to the FISA court's ruling could be liable for committing a crime and possibly an impeachable offense.

The proposal does not limit the state's fundamental right to selfdefense. Rather, it creates a process seeking to objectify counterterrorism by seeking to establish standards for determining whether intelligence information is admissible.

The practical impact? A drone policy predicated on the rule of law, morality in armed conflict and articulation of policy effectiveness. 